\title{
Assessment of Risk Levels of Mangrove Forest Due to Oil Spill in Muara Gembong, Bekasi Regency
}

\author{
Dena Indriawan ${ }^{1 *}$, Ankiq Taofiqurrohman ${ }^{2}$, Indah Riyantini², Ibnu Faizal ${ }^{2}$ \\ ${ }^{1}$ Marine Science Study Program, Faculty of Fisheries and Marine Sciences, Padjadjaran University. Raya Bandung Sumedang \\ KM.21, Hegarmanah, Kec. Jatinangor, Sumedang Regency, West Java 45363 \\ ${ }^{2}$ Department of Marine Science, Faculty of Fisheries and Marine Sciences, Padjadjaran University. Raya Bandung Sumedang \\ KM.21, Hegarmanah, Kec. Jatinangor, Sumedang Regency, West Java 45363
}

\begin{abstract}
Habitat risk assessment is critical to assess the state of an environment. This research was conducted with the aim to assessand map the risk value of Mangrove Forest due to the oil spill incident in the Muara Gembong Regency, Bekasi District, which previously polluted coastal areas, especially in the mangrove ecosystem. Risk assessment is carried out as an effort to mitigate disaster to have a better prevention strategy, especially in areas that have a higher risk. The method for assessing risk in the mangrove ecosystem in Muara Gembong uses Habitat Risk Assessment using the Euclidean Distance formula, which is divided into three risk classes: low, medium, high. The risk value in coastal areas prone to oil spills has a moderate risk value with a total area of $3.7 \mathrm{~km} 2$ because the mangrove ecosystem has good resilience, and low risk for the inner mangrove area of the coastal area has a low chance with an area of $2.85 \mathrm{~km} 2$. The risk value in the medium class is 1.02, and the risk value in the low rank is 0.11 .
\end{abstract}

Keywords: Muara Gembong, Habitat Risk Assessment, Mangrove, Oil Spill

\section{Introduction}

The area of mangroves in Indonesia is $23 \%$ of the total area of the world's mangrove ecosystems [1]. Mangroves have ecological functions, including nursery ground, feeding ground, spawning ground, nutrient provider, coastal abrasion protection, natural breakwater, waste absorber, and prevention of seawater intrusion [2,3]. In addition to having an ecological function, mangrove forests have a socio-economic role, namely providing ecosystem services beneficial to coastal communities, such as stabilization and storm protection [4]. Unfortunately, Mangrove Forest has continued to experience degradation in the last few decades. It also has been reported that more than $50 \%$ of the total mangrove forest in Indonesia has been damaged [5]. The Damage to mangroves are caused by three main factors, namely pollution, conversion of mangrove forests that do not pay attention to environmental factors, and excessive logging [6]. This places the mangrove habitat at risk of future damage. Efforts to assess the threat from the impact of human activities in coastal and marine ecosystem areas need to be carried out by determining cumulative impacts, and mapping risks to habitats and disaster mitigation can be carried out [7].

Oil spills are one of the risks due to human activities in marine and coastal waters. On July 21, 2019, there was an oil spill due to an oil pipe leak in the YYA-1 well of the Offshore North West Java (ONWJ) Block belonging to Pertamina. [8]. Oil spill from a well owned by Pertamina Hulu Energi Offshore North West Java (PHE ONWJ) in the Karawang sea waters was caused by the re-entry process when drilling [9]. The areas affected by this spill were Karawang district, Bekasi district to the Thousand Islands because they were carried away by the current. Oil is a marine pollutant with toxic properties because it contains organic compounds Polycyclic

Aromatic Hydrocarbons (PAH). PAHs are one of the significant marine contaminants [10]. High PAH levels are often found in sediments in coastal areas through oceanographic processes and settle there for a long time [11-14].

Information is needed regarding the risk of damage to mangrove forests affected by oil spills by assessing the level of risk of mangrove forests due to oil spills as a stressor in the Muara Gembong area. Natural Capital Project creates InVEST (Integrated Valuation of Ecosystem Services and Trade-offs), which is software for mapping for ecosystems in both land and sea areas (http://www.naturalcapitalproject.org/invest/). The program used in InVEST for this research is the Habitat Risk Assessment (HRA) to assess habitat risk from existing stressors, which in this study is an oil spill. A Habitat Risk Assessment is needed to review the risk of habitat degradation in coastal areas to determine appropriate management steps $[15,16]$. The expectation from the habitat risk assessment is that the government and private parties operating in the area can have

\footnotetext{
*Corresponding author: dena17002@mail.unpad.ac.id
} 
sustainable coastal management following the level of habitat risk. [17,18]

You are free to use colour illustrations for the online version of the proceedings but any print version will be printed in black and white unless special arrangements have been made with the conference organiser. Please check whether or not this is the case. If the print version will be black and white only, you should check your figure captions carefully and remove any reference to colour in the illustration and text. In addition, some colour figures will degrade or suffer loss of information when converted to black and white, and this should be taken into account when preparing them.

\section{Methods}

\subsection{Research Location}

The research was conducted in Muara Gembong District, Bekasi Regency, which is one of the areas affected by the oil spill. Muara Gembong District has an area of $154.6 \mathrm{~km}^{2}$ consisting of 6 villages, namely Pantai Mekar village, Pantai Sederhana village, Jayasakti village, Pantai Harapan Jaya village, Pantai Bakti village dan Pantai Bahagia village. The water area of Muara Gembong, which is part of the Java Sea, was also affected by the oil spill from YYA-1 Block ONWJ, which was carried away by the current.



Figure 1. Research Map in Muara Gembong Area.

The point in the Karawang Regency area is the YYA1 Well where the oil spill occurred. The red color indicates the research area and Green represents mangrove vegetation.

\subsection{Data Set}

The data used in this research are in the form of consequence data and data on the distribution of oil spills as stressors which will be used for data on habitat exposure by stressors by conducting a literature study. The habitat studied in this research is mangrove in Muara Gembong District, Bekasi Regency. The spatial data required was used to process Sentinel-2 Image Data for processing mangrove cover area data and Sentinel-1 Image Data to determine the distribution of oil spills in the waters of Muara Gembong District, Bekasi Regency. conducted to obtain the appropriate information in the research. This research combines several of the latest methods to produce more comprehensive and valid
results.Interviews with resource persons in the study area were also.

\section{Data Analysis}

The data needed to assess the level of risk of the object under study is an information scale to assesst the risk level $[19,20]$. This data will be entered calculated through the InVEST software, so that it has a spatial risk level value and also on the Euclidean chart.

Table 1. Classification of Stressor exposure Index and Value $[19,20]$

\begin{tabular}{|l|l|l|l|}
\hline \multirow{2}{*}{ Description } & \multicolumn{3}{|c|}{ Score (Value) } \\
\cline { 2 - 4 } & High (3) & Medium (2) & \multicolumn{1}{|c|}{ Low (1) } \\
\hline Area Overlap & $\begin{array}{l}\text { More than } \\
\begin{array}{l}30 \% \text { of } \\
\text { habitats } \\
\text { overlap } \\
\text { with } \\
\text { stressors }\end{array}\end{array}$ & $\begin{array}{l}10 \%-30 \% \\
\text { of habitats } \\
\text { overlap } \\
\text { with } \\
\text { stressors }\end{array}$ & $\begin{array}{l}\text { Less than } \\
10 \% \text { of } \\
\text { habitats } \\
\text { overlap with } \\
\text { stressors }\end{array}$ \\
\hline $\begin{array}{l}\text { Duration of } \\
\text { Overlap }\end{array}$ & $\begin{array}{l}\text { Occurs for } \\
8-12 \\
\text { months of } \\
\text { the year }\end{array}$ & $\begin{array}{l}\text { Occurs for } \\
\text { during 4-8 } \\
\text { months of } \\
\text { the year }\end{array}$ & $\begin{array}{l}\text { Occurs 0 - } \\
\text { months of } \\
\text { the year }\end{array}$ \\
\hline $\begin{array}{l}\text { Stressor } \\
\text { intensity } \\
\text { level }\end{array}$ & $\begin{array}{l}\text { The impact } \\
\text { of stressors } \\
\text { on habitat } \\
\text { is high }\end{array}$ & $\begin{array}{l}\text { The impact } \\
\text { of stressors } \\
\text { on habitat } \\
\text { is medium }\end{array}$ & $\begin{array}{l}\text { Impact of } \\
\text { stressors on } \\
\text { habitat is } \\
\text { low }\end{array}$ \\
\hline $\begin{array}{l}\text { Supervision } \\
\text { Management }\end{array}$ & $\begin{array}{l}\text { No } \\
\text { preventive } \\
\text { process }\end{array}$ & $\begin{array}{l}\text { There's a } \\
\text { precaution, } \\
\text { but the } \\
\text { problems } \\
\text { always } \\
\text { happen }\end{array}$ & $\begin{array}{l}\text { There are } \\
\text { precautions } \\
\text { that resulted } \\
\text { in no } \\
\text { reoccurrence }\end{array}$ \\
\hline
\end{tabular}

The Consequence Index and Value were used to assess the resilience of the studied habitats. The assessed aspects can be seen more clearly in Table 2 .

Table 2. Consequence Index and Value [19,20]

\begin{tabular}{|l|l|l|l|}
\hline \multirow{2}{*}{ Description } & \multicolumn{3}{|c|}{ Score (Value) } \\
\cline { 2 - 4 } & High (3) & \multicolumn{1}{|c|}{$\begin{array}{c}\text { Medium } \\
(2)\end{array}$} & \multicolumn{1}{|c|}{ Low (1) } \\
\hline $\begin{array}{l}\text { Changes in } \\
\text { habitat area }\end{array}$ & $\begin{array}{l}\text { Losing } \\
50- \\
100 \% \text { of } \\
\text { the total } \\
\text { area }\end{array}$ & $\begin{array}{l}\text { Losing 20 } \\
-50 \% \text { of } \\
\text { the total } \\
\text { area }\end{array}$ & $\begin{array}{l}\text { Lossless than } \\
20 \% \text { of the } \\
\text { total area }\end{array}$ \\
\hline $\begin{array}{l}\text { Changes in } \\
\text { habitat } \\
\text { structure }\end{array}$ & $\begin{array}{l}\text { Changes } \\
\text { in habitat } \\
\text { structure } \\
\text { occur as } \\
\text { much as }\end{array}$ & $\begin{array}{l}\text { Changes } \\
\text { in habitat } \\
\text { structure } \\
\text { occur as } \\
\text { much as } \\
\text { 50-100\% }\end{array}$ & $\begin{array}{l}\text { Changes in } \\
\text { habitat } \\
\text { structure } \\
\text { occur as much } \\
\text { as 0-20\% }\end{array}$ \\
\hline $\begin{array}{l}\text { Natural } \\
\text { disturbance } \\
\text { frequency }\end{array}$ & $\begin{array}{l}\text { Available } \\
\text { on an } \\
\text { annual } \\
\text { period }\end{array}$ & $\begin{array}{l}\text { Available } \\
\text { in } \\
\text { seasonal } \\
\text { period }\end{array}$ & $\begin{array}{l}\text { Available on } \\
\text { weekly and } \\
\text { daily periods }\end{array}$ \\
\hline $\begin{array}{l}\text { Natural } \\
\text { mortality }\end{array}$ & $\begin{array}{l}\text { Mortality } \\
\text { rate } 0-\end{array}$ & $\begin{array}{l}\text { Mortality } \\
\text { rate 20 }- \\
50 \%\end{array}$ & $\begin{array}{l}\text { More than } \\
50 \% \text { mortality } \\
\text { rate }\end{array}$ \\
\hline
\end{tabular}




\begin{tabular}{|l|l|l|l|}
\hline \multirow{2}{*}{ Description } & \multicolumn{3}{|c|}{ Score (Value) } \\
\cline { 2 - 4 } & High (3) & \multicolumn{1}{|c|}{$\begin{array}{c}\text { Medium } \\
(2)\end{array}$} & \multicolumn{1}{|c|}{ Low (1) } \\
\hline Recruitment & $\begin{array}{l}\text { More } \\
\text { than 2 } \\
\text { years }\end{array}$ & $\begin{array}{l}\text { Between } \\
1-2 \\
\text { year(s) }\end{array}$ & $\begin{array}{l}\text { Less than a } \\
\text { year }\end{array}$ \\
\hline Recovery time & $\begin{array}{l}\text { More } \\
\text { than 10 } \\
\text { years }\end{array}$ & $\begin{array}{l}\text { Between } \\
1-10 \\
\text { years }\end{array}$ & $\begin{array}{l}\text { Less than a } \\
\text { year }\end{array}$ \\
\hline Connectivity & $\begin{array}{l}\text { Less than } \\
10 \mathrm{~km}\end{array}$ & $\begin{array}{l}\text { Between } \\
10-10 \\
\mathrm{~km}\end{array}$ & $\begin{array}{l}\text { More than } \\
100 \mathrm{~km}\end{array}$ \\
& & \multicolumn{2}{|l}{} \\
\hline
\end{tabular}

The Euclidean algorithm allows users to assess the cumulative risk posed to habitats by human activities and to assess the consequences of exploiting ecosystems [21-23]. This method combines two pieces of information, namely habitat stressors and habitat resistance to exposure to stressors. The Euclidean equation is as follows:

$\mathrm{R}=\sqrt{(E-1)^{2}+(C-1)^{2}}$

$\mathrm{E}=\frac{\sum_{i=1}^{N} \frac{e_{i}}{d_{i}}}{\sum_{i=1}^{N} \frac{1}{d_{i}}}$

$\mathrm{C}=\frac{\sum_{i=1}^{N} \frac{c_{i}}{d_{i}}}{\sum_{i=1}^{N} \frac{1}{d_{i}}}$

Where:

$\mathrm{R}$ : Habitat risk level index

E : Habitat exposure to stressors

C : Habitat resistance to exposure

ei : Stressor score

ci : Habitat consequence score

di : Data Quality

Each habitat is classified as low, medium, or high risk based on the cumulative effect of the stressor. The maximum risk score (high) is given at a value of $>66 \%$ of the total maximum risk. If stressor exposure and consequence use a scale of 1-3, then the maximum risk score for habitat is 2.83 (using the Euclidean scale) (Sharp et al., 2018). Thus, a risk score of more than 1.87 (66\% of 2.83$)$ is classified as high risk. This criterion states that the effects of stress are very damaging. Risk is classified as moderate risk if it has a cumulative risk score between $33 \%-66 \%$ of the total cumulative risk score. Risks are classified as low risk if they have an individual or cumulative risk score of $0-33 \%$ of the total risk score. [19,20,22]

\section{Results and Discussion}

Based on image data from research conducted in the same period, there was a change in the area of mangroves in Muara Gembong District in the period 2018 - 2020. The total area of mangroves in 2018 was $36.73 \mathrm{~km}^{2}$, while in 2020 , the area of mangroves decreased by $6 \%$ or as much as $2.07 \mathrm{~km}^{2}$ to $34.66 \mathrm{~km}^{2}$. The oil spill that overlaps the mangrove area is $13 \%$ of the total area of $4.51 \mathrm{~km}^{2}$.
Oil spills in the Karawang waters are carried by currents influenced by wind direction. When a leak occurs in the YYA-1 pipeline, the wind direction moves from east to west, thus bringing the oil spill to the Muara Gembong waters [24]. The identification results were strengthened by discovering an oil spill in the area of Pantai Muara Bungin, Pantai Beting, Pantai Mekar dan Pantai Bahagia [25].

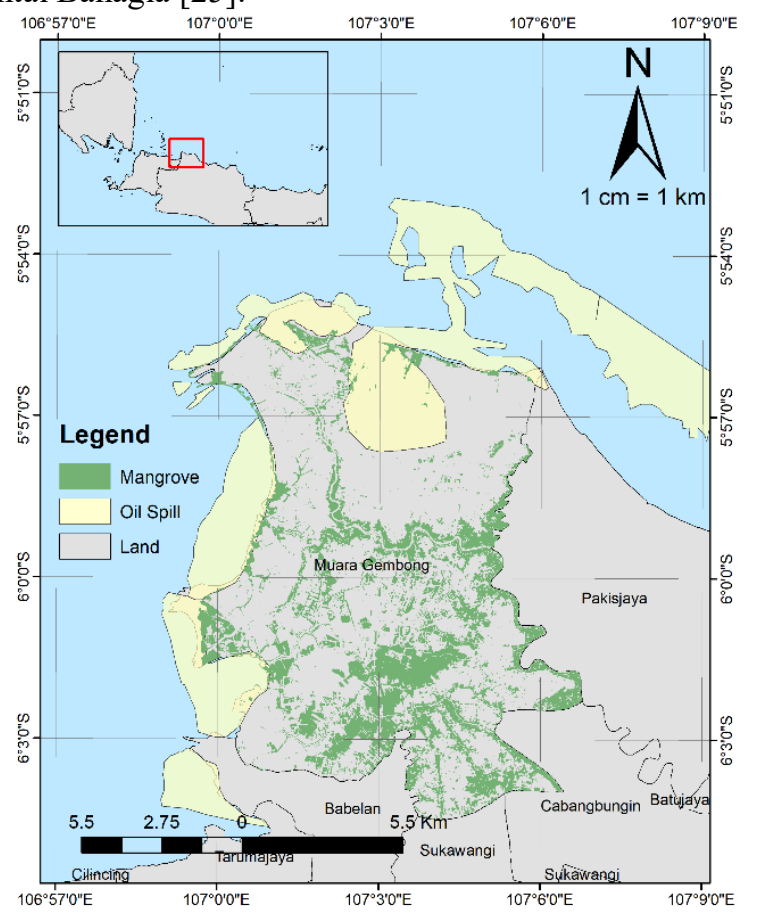

Figure 2. Spatial data of mangroves and oil. Green Indicates mangrove and yellow areas identified as oil spill

The classification exposure of stressors and consequence is filled by conducting a literature study on related aspects. In the element of consequence, the area of mangrove forests has a change of $6 \%$ in the range of 2018 - 2020 so that it is categorized in the low criteria. Changes in habitat structure are also consideredinferior due to good handling in the form of restoration processes from various related parties in cases in 2019 [9,26]. The frequency of a yearly disturbances in Muara Gembong is in the form of tidal [27,28]. Tidal floods have an annual period, so they are categorized as high criteria. A less frequent occurrence is classed as higher risk because if a habitat is naturally disturbed like anthropogenic stressors, it may be more resistant to additional stress [19].

The natural mortality rate of mangroves is $16 \%$ $19 \%$. This causes mangroves to get high criteria because a high natural mortality rate is considered more productive and more able to recover. After allthe reproduction process is faster and occurs frequently. $[19,29]$. The time to mature (trees) for mangroves is five years [30]. Meanwhile, the rate of spread of propagules is categorized as low because propagules require nutrients from the parent to last a long [31]. It was explained that the most distant mangrove propagules could be spread as far as 1-2 km from the parent before sinking due to loss of buoyancy [32]. Data processing Oil spills from sentinel-1 images found in the waters of Muara Gembong District have been identified and the 
overlap area has been calculated, which reaches $13 \%$ of the total mangrove area. The duration of the oil spill is also known from July to November 2019, occurred 5 months, so it is categorized in the medium criteria. $[9,24]$

Various sources state that oil has a degradation process that takes years, which is often a problem because the environment around the oil spill has been polluted [11,12,33-35]. Despite that, the case in Muara Gembong is different because of the excellent and fast handling of Pertamina and the locals who helped the process [36]. CSR funding assistance and replanting which contributed up to 19,000 mangrove seedlings, also decreased to reduce the impact that had occurred [26]. From the results of field validation, no remaining crude oil was found in the coastal area of Muara Gembong. The results of the questionnaire also show a high level of awareness of the people of Muara Gembong on the impact and risk of oil spills on the mangrove ecosystem. Therefore residents take an active role in the process of cleaning up oil on the coast.

The effects of oil spills can cause the death of mangroves, such as the death of stands, carcinogenic, and mutagenic effects on mangroves, closing mangrove roots so that it is difficult to absorb oxygen and also the death of animals associated with mangroves. [19,37,38]. Therefore, the level of stressor intensity is categorized as high. Supervision management is categorized as moderate because the oil spill incident by Pertamina is not the first time despite preventive measures. Among others, such as in Balikpapan Bay, East Kalimantan, and on the North Coast of Karawang, West Java $[39,40]$. The prevention processes carried out include the use of ships for the elimination process in waters, oil booms, and oil collection in coastal areas. [41]

In general, areas with moderate risk are located in coastal areas, and low-risk areas follow behind low-risk areas. Mangrove areas far from the coast do not have a risk value because they are far from the waters. The high-risk value is not found in any area, while the medium risk has an area of $3.7 \mathrm{~km}^{2}$, and the low risk is $2.85 \mathrm{~km}^{2}$. The place that does not have a high risk of oil spills is $28.11 \mathrm{~km}^{2}$.

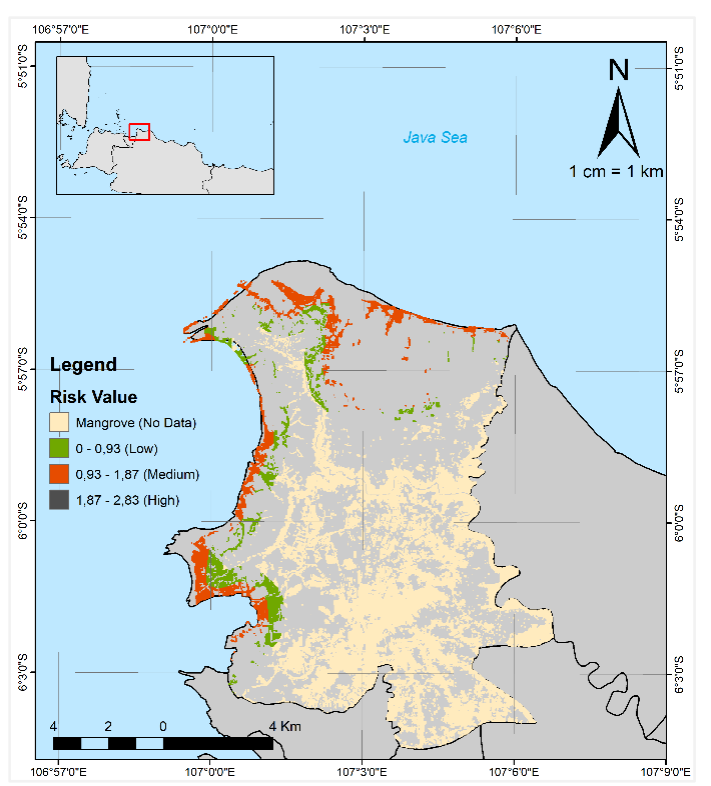

Figure 3. Map of the Distribution of Mangrove Risk due to Oil Spills. There are two risk classes in this research, namely moderate and low.

The value on the Euclidean chart on the risk assessment of mangrove forests due to oil spills at the medium risk value has an $\mathrm{E}$ value (habitat exposure) of 1.7 and a $C$ value (consequence) of 1.75 . So, it has an $R$ value of 1.02. At the low-risk value, the $\mathrm{R}$ value is 0.11 with an $E$ value of 0.93 and a $C$ value of 0.92 .

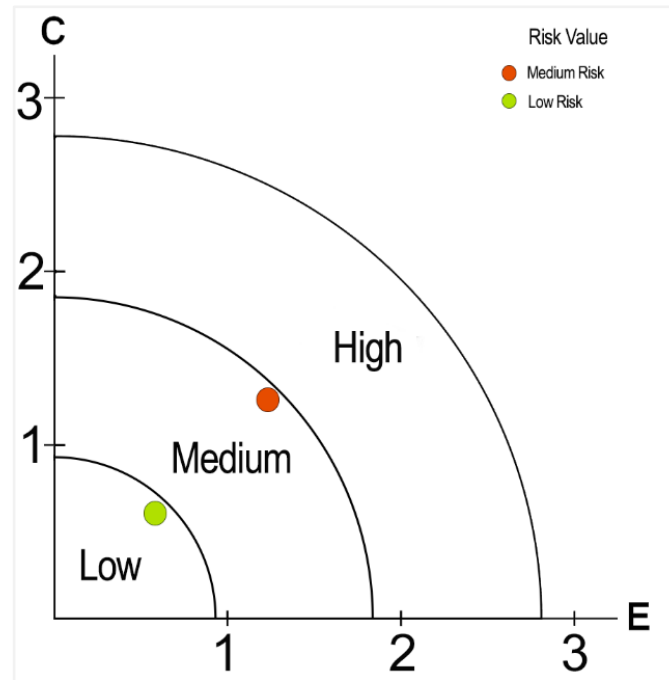

Figure 4. Risk Graphic

Mangroves located in coastal areas have the highest (medium) risk value because these areas are in direct contact with areas identified as oil spills, making them the most vulnerable areas to be affected by damage [42]. Meanwhile, mangrove areas that have low risk are behind areas that have low risk because they are still relatively close to coastal areas. Biota associated with mangroves and mangroves themselves will be exposed to the carcinogenic and mutagenic effects of oil spills, thus disrupting the growth and reproduction processes. $[37,43]$.

\section{Conclusion}

Based on the results and discussions that have been described, conclusions can be drawn regarding the assessment of the risk level of mangrove forests due to oil spills in Muara Gembong District, Bekasi Regency. The Euclidean value for the risk of mangrove forests in Muara Gembong District, Bekasi Regency is 1.02 for moderate risk, and 0.11 for low risk. The highest risk level in the mangroves of Muara Gembong District, Bekasi Regency is at a medium level with an area of 3.7 $\mathrm{km}^{2}$ and is located in a coastal area. This is because the site is in direct contact with the site where the oil spill was found. The low-risk mangrove has an area of 2.85 $\mathrm{km}^{2}$ which is located behind the medium risk area because it still has the possibility of being affected by the ecosystem area that is in direct contact with the oil spill. Mangroves that do not have a risk score for oil spills have an area of $28.11 \mathrm{~km}^{2}$ because they are far from the coast. 


\section{References}

1. N. Latifah, S. Febrianto, H. Endrawati, and M. Zainuri, Jurnal Kelautan Tropis 21, 97 (2018).

2. S. Nur Rahmasari, F. Agus, D. Muningsih, and W. T. Gantini, Jurnal Resolusi Konflik, CSR, Dan Pemberdayaan 4, 35 (2019).

3. S. Syahrial, N. Purwanti, H. Adelina Meria Uli Sagala, N. Atikah, Y. Sari, B. Oktavian, and N. Simbolon, Jurnal Ilmiah Perikanan Dan Kelautan 11, 9 (2019).

4. B. S. Muntalif, O. Hasian, and E. Sembiring, Jurnal Teknik Lingkungan 19, 82 (2013).

5. Ahnanto, E. Syahpirudin, I. Purba Waskita, Novita, S. Hartati, A. Tjala, and M. Zid, SPATIAL Wahana Komunikasi Dan Informasi Geografi 12, 2 (2014).

6. E. Poedjirahajoe, R. Widyorini, and N. P. D. M. Mahayani, Jurnal Ilmu Kehutanan 5, 99 (2011).

7. K. H. Wyatt, R. Griffin, A. D. Guerry, M. Ruckelshaus, M. Fogarty, and K. K. Arkema, PLOS ONE 12, 1 (2017).

8. A. Dwi and W. Adi, Tempo.Co 1 (2019).

9. PHE (Pertamina Hulu Energi), Pertamina (2019).

10. J. H. Steele, S. A. Thorpe, and K. K. Turekian, Encyclopedia of Ocean Sciences, 2nd ed. (London, 2011).

11. F. Ahmad, ILMU KELAUTAN: Indonesian Journal of Marine Sciences 17, 199 (2013).

12. C. C. Hung, G. C. Gong, F. C. Ko, H. J. Lee, H. Y. Chen, J. M. Wu, M. L. Hsu, S. C. Peng, F. H. Nan, and P. H. Santschi, Marine Pollution Bulletin 63, 464 (2011).

13. K. Munawir and D. Yogaswara, Bulletin of the Marine Geology 32, 61 (2017).

14. A. O. Adeniji, O. O. Okoh, and A. I. Okoh, Intech i, 37 (2017).

15. M. G. Chung, H. Kang, and S. U. Choi, PLoS ONE 10, 1 (2015).

16. C. I. Elliff and R. K. P. Kikuchi, Ocean and Coastal Management 136, 49 (2017).

17. A. A. Fisu, A. Ahmad, A. Hidayat, and L. U. Marzaman, Edutourism Journal Of Tourism Research 2, 11 (2020).

18. B. Nugraha, I. Sukri Banuwa, and S. Widagdo, Jurnal Sylva Lestari 3, 53 (2015).

19. K. K. Arkema, G. Verutes, J. R. Bernhardt, C. Clarke, S. Rosado, M. Canto, S. A. Wood, M. Ruckelshaus, A. Rosenthal, M. McField, and J. de Zegher, Environmental Research Letters 9, (2014).

20. A. Taofiqurohman, Depik 2, 50 (2013).

21. Coastal Zone Management Authority and Institute (CZMAI), Minsitry of Agriculture, Forestry, Fisheries, and the Environment \& Sustainable Development 265 (2016).

22. Natural Capital Project, Stanford University (2014).

23. E. Ramanujam, H. Carter, J. Samhouri, and J. Bizzaro, Ecological Risk Assessment as a Prioritization Tool to Support California Fisheries Management (Ocean Science TrUST, Oaklan, California, 2017).
24. A. Abimanyu, W. S. Pranowo, I. Faizal, N. K. A. Afandi, and N. P. Purba, Geography, Environment, Sustainability 14, 177 (2021).

25. G. Buana, Media Indonesia (2019).

26. Y. P. Wulandari, N. Raysina, and D. Muningsih, Jurnal Care: Jurnal Resolusi Konflik, Csr, Dan Pemberdayaan 4, 43 (2019).

27. A. Maulani, N. Taufiq-spj, and I. Pratikto, 10, 55 (2021).

28. A. S. Nastiti, Mujianto, M. R. A. Putri, D. A. Hedianto, Indriatmoko, and J. Haryadi, 6, 8 (2021).

29. J. A. Jimenez, A. E. Lugo, G. Cintron, J. A. Jimenez, A. E. Lugo, U. F. Service, and P. O. B. Aq, The Association for Tropical Biology and Conservation 17, 177 (2012).

30. N. Muharrahmi, R. Budihastuti, and E. D. Hastuti, Journal Biologi 5, 60 (2016).

31. M. Sun, K. C. Wong, and J. S. Y. Lee, American Journal of Botany 85, 1631 (1998).

32. W. P. Sousa, P. G. Kennedy, B. J. Mitchell, and B. M. Ordóñez L, Ecological Monographs 77, 53 (2007).

33. P. F. Kingston, Spill Science and Technology Bulletin 7, 53 (2002).

34. I. Berenshtein, S. O'Farrell, N. Perlin, J. N. Sanchirico, S. A. Murawski, L. Perruso, C. B. Paris, and M. Gibbs, ICES Journal of Marine Science 76, 2276 (2019).

35. B. Latif, A. Kurniawan, and I. Manggala Ayubi, Jurnal Magister Hukum Udayana (Udayana Master Law Journal) 7, 133 (2018).

36. A. Nugroho, Merdeka (2019).

37. J. Michel and M. Fingas, Oil Exploration: Causes, Consequences, Prevention, and Countermeasures (2017).

38. K. K. Arkema, G. M. Verutes, S. A. Wood, C. Clarke-Samuels, S. Rosado, M. Canto, A. Rosenthal, M. Ruckelshaus, G. Guannel, J. Toft, J. Faries, J. M. Silver, R. Griffin, and A. D. Guerry, Proceedings of the National Academy of Sciences of the United States of America 112, 7390 (2015).

39. L. Arumingtyas and D. Syahni, Mongabay (2019).

40. J. Iskandar, Kompas (2021).

41. BBC, BBC NEWS (2019).

42. M. K. Wardhani and S. Vincentius, Jurnal Ilmiah Perikanan Dan Kelautan 3, 211 (2011).

43. Z. Hidayah, Jurnal Ilmiah Perikanan Dan Kelautan 3, 24 (2011). 